Mediterranean Journal of Humanities mjh.akdeniz.edu.tr I/2, 2011, 1-20

\title{
Teachers’ Views on Constructivism in Turkish Primary EFL Classes
}

\author{
Türkiye’deki İlköğretim İngilizce Derslerinde Yapılandırmacılı Üzerine \\ Ö̆̆retmen Görüşleri
}

\begin{abstract}
Arif BAKLA*
Abstract: This study starts with a brief description of both what constructivism is, and its place in foreign language teaching literature. This literature review includes not only the theoretical dimension of the concept, but also over those practical studies with a constructivist focus. This study aims to find out how this theory is put into practice in Turkish EFL classes in primary schools. In order to obtain a robust understanding of the current situation of constructivism in primary EFL classes in Turkey, the researcher developed a survey for EFL teachers working in primary schools in the province of Konya. The data collection tool was designed to uncover issues regarding; (1) the implementation of constructivist learning principles in lessons (2) practical problems that are likely to emerge in the classroom (3) how constructivist principles are put into practice in the course books provided by the Ministry of Education. The Cronbach's Alpha coefficient of the survey, analysed by using SPSS 15.0, was .752. The results revealed what English teachers, as significant stakeholders in primary school education, thought about the current situation and the practice of constructivism in primary school EFL classes. The independent samples t-test and analysis of variance results showed that there were no statistically meaningful differences between sexes except for one item in the questionnaire; similarly, no statistically significant differences were found between teachers with a BA and those with MA degrees, except for one item. Moreover, analysis has not revealed any significant differences between ELT and non-ELT graduates. The study ends with a discussion of the results of the survey.
\end{abstract}

Keywords: Constructivism, English language teacher, primary education

Özet: Bu çalışma yapılandırmacılığın temellerinin ve yabancı dil öğretimi alan yazınındaki yerinin kısa bir betimlemesi ile başlamaktadır. Alan yazın taraması bu kavramın sadece kuramsal boyutunu içermekle kalmayıp, aynı zamanda yapılandırmacılık odaklı uygulamalı çalışmalara da değinmektedir. Bu çalışma temel olarak Türkiye'deki ilköğretim okulundaki İngilizce derslerinde yapılandırmacılığın nasıl uygulandığını ortaya ortaya koymayı hedeflemektedir. Yapılandırmacılığın Turkiye'deki durumunu tam olarak anlamak için, araştırmacı Konya ilinde ilköğretim okullarında çalışan İngilizce öğretmenleri için bir anket geliştirmiştir. Bu veri toplama aracı (1) yapılandırmacılığın temel prensiplerinin sınıf içinde uygulamaya konulmasını (2) uygulama sırasında meydana gelebilecek olası problemleri (3) yapılandırmacılığın prensiplerinin Milli Eğitim Bakanlığı tarafından dağıtılmış olan kitaplarda nasıl uygulamaya konulduğunu ortaya çıkarmak için geliştirilmiştir. SPSS 15.0 ile analiz edilen anketin Cronbach Alpha değeri .752 olarak bulunmuştur. Anket sonuçları İlköğretim eğitiminde önemli bir paydaş olan İngilizce öğretmenlerinin yapılandırmacılığın şu anki durumu ve uygulanması konusunda ne düşündüklerini ortaya koymuştur. T-test ve ANOVA sonuçları anket maddelerinin biri hariç diğerlerinde cinsiyete göre istatistiksel anlamda önemli bir fark olmadığını göstermiştir. Benzer şekilde, öğretmenlerin lisans veya yüksek lisans mezunu olmaları da istatistiksel açıdan önemli bir farka sebep olmamıştır. Ayrıca, analizler İngilizce Öğretmenliği bölümü mezunu olanlar ile olmayanlar arasında da önemli bir fark olmadığını göstermiştir. Bu çalışma anket sonuçlarının tarışması ile sona ermektedir.

Anahtar Sözcükler: Yapılandırmacılık, İngilizce öğretmeni, ilköğretim

\footnotetext{
*PhD. Candidate, Hacettepe University; Instructor at Selcuk University, arifbakla@gmail.com
} 
The educational reform of 2005 in Turkey brought about a curricular innovation that entailed the introduction of a constructivist philosophy into foreign language classes as was the case for other lessons. This was largely because the traditional focus on the one-way transmission of knowledge from teacher to students was intended to be replaced by productive practices of learning in a constructivist environment. That is, advocates of constructivist philosophy believe that learners actively construct knowledge in their attempts to make sense of their world. The latest instructional developments in primary school EFL classrooms are investigated in this study covering both the theoretical and practical dimensions of the issue.

It is often stressed in texts on constructivism that this approach has more to do with learning than it does with teaching. As the name suggests, it involves learners' constructing knowledge on a step by step basis. This approach often focuses on how learners construct and interpret knowledge. Unlike traditional approaches in which information is passed onto learners, learners themselves gain access to information through books and from other sources. In either case, there is a one-way transmission of knowledge from a more knowledgeable source to the learners. Therefore, the intellectual process that goes on in the mind of the learner does not go beyond perception or comprehension. Why is constructivism at odds with knowledge transfer? Constructivist teachers do not transfer knowledge because each learner has to build up his or her own knowledge; concepts cannot be transferred from teacher to learner through words (von Glasersfeld, 1995; Nuthall, 2002). That's why knowledge absorption is not seen as viable among constructivists.

This study is an attempt to discover the extent to which the theory meets the practice in the Turkish primary school English classroom as far as constructivist foreign language teaching pedagogy is concerned. In other words, to find out whether constructivism is effectively practised in Turkish primary EFL classes, it attempts to expose the challenges apparent during implementation. In addition to understanding the nature of changes that occurred in teacher and learner roles in the classroom, the researcher seeks to discover the challenges involved in the implementation of the constructivist learning principles from the viewpoint of EFL teachers working at Turkish primary schools.

\section{An Overview of Constructivism}

Tobias and Duffy (2009) stress that the roots of constructivism can be traced back to an Italian philosopher, Giambattista Vico, who lived in the early 18th century (p. 3), while Murphy (1997) associates this approach with an earlier scientific mind, Socrates, who liked to ask his students to challenge various issues. It would be not wrong to claim that there is a close link between constructivist epistemology and the questioning technique of Socrates, who stressed the importance of meaning making processes through asking and answering questions. This close link is the result of our natural tendency to question all the time (Johnston, 2007). To whoever the roots are traced back to, it is clear that constructivism is a product of an eclectic philosophy that is not new.

Although the constructivist approach has a long tradition, the growing interest in constructivism can be attributed to the more recent works of some modern researchers. Among these latest researchers are two that provide us with a general framework for this issue. Ayas $(2006,5)$ stresses that "constructivism entered mainstream educational thought and research in the 1970s through the work of the disciples of Piaget and Vygotsky". The former favoured a cognitive view of constructivism, while the latter pioneered works in social constructivism. Knowledge is the natural result of learner experiences and the interaction between the learner and his/her environment. Learning is both an individual and social process. Phillips and Soltis (1998, 50) stress that Piaget's theory about how young learners build up knowledge has been a source of 
seventh and eighth grades have a four-hour compulsory and a two-hour elective course. In accordance with the syllabus, the books for all grades have two sections. The first section focuses on new points (both grammatical and lexical) the second is for consolidation. The syllabus suggests that tasks or projects assigned to learners at the end of each unit can be kept in a dossier by the students, and teachers can provide feedback to those after the consolidation unit in the elective course hours. Students can also share their projects with their peers in the class (Ministry of Education, 2006).

\section{Data Collection Tool}

In the framework of this study, a 26-item survey helped the researcher to collect data. Several steps were followed in the process of survey design. Firstly, an in-depth literature review was done to examine existing studies on constructivist learning, mostly dealing with teacher opinions or constructivism in general. Particularly the studies concerning administrated surveys or checklists regarding constructivism (Çınar, et al., 2005; Küçüközer, et al., 2005; Can, 2006; Sert, 2008) were examined. Previous studies concerning constructivist learning in general and specifically what teachers thought about the implementational aspects were scrutinized to obtain an overall idea of the subject. In addition, the main issues regarding constructivist pedagogy were made clear.

Since it is often advised to carry out a small-scale qualitative study with the respondents before item construction (e.g. Dörnyei, 2003, 31), following the literature review, a homogenous group of 5 teachers who were randomly chosen to be representative of the respondents were asked to brainstorm about constructivist language pedagogy before they were asked to take part in a structured interview. The interview consisted of the following questions: (1) What is your understanding of constructivist foreign language teaching? (2) Do you think constructivist principles can successfully be put into practice in EFL classes in Turkish primary schools? (3) What are the main challenges that emerge when you try to conduct a constructivist lesson? (4) If you face any problems, what solutions can you offer to solve them? (5) Do you think the syllabus for each grade conforms to constructivist principles? (6) Does the course book that you follow conform to constructivist principles? (7) Do you think there is a clear gap between the theory and practice of constructivism in primary school English classes in Turkey? (8) In general, how do you evaluate the success of constructivist language teaching practices in primary English classes in Turkey?

The questions of the structured interview were formulated in English. They were also translated into Turkish to be used during the construction of the questionnaire and for later reference. Some of the issues mentioned by the teachers helped the researcher to formulate items during the process of item construction. For example, one of the commonly mentioned problems was that they did not have enough time to cover all the subjects assigned in the syllabus. Another was that there was a significant gap not only between theory and practice, but also between teaching and testing. In order to find out about more about these issues, items were formulated and put into the questionnaire.

The literature review, and brainstorming done by the teachers on the issue and interviews helped the researcher to obtain a clear understanding of the main points of constructivist pedagogy to construct statements that contained both the theoretical and practical aspects of the issue. 30 Likert items were designed to that end. A five-point scale, including the expressions "Strongly agree", "Agree", "Disagree", "Strongly disagree" and "No idea" accompanied these statements to label what teachers thought. A descriptive title was provided at the top of the page to provide the respondents with an initial impression. Moreover, at the beginning of the attitude scale form, what respondents are required to do was explained briefly so as to provide clear-cut directions to follow. The following table gives more specific information about the data collection tool. 
meaningful difference between male or female teachers in terms of the responses to each item in the survey, it seemed rather difficult to find meaningful differences due to this disparity between male and female respondents.

\section{Data Analysis}

SPSS 15.0 was also used to carry out statistical procedures to analyse the results. Overall scale internal consistency reliability was estimated. That is, the Cronbach's Alpha coefficient for the questionnaire was .733 if one of the items was deleted (Item 23). The reliability coefficient for the survey was .696 before the deletion of the item mentioned above, so one item which had the highest negative value for the corrected item-total correlations (the Item 23) was deleted to render the survey more reliable. Considering that the Cronbach's Alpha value above 6 is considered acceptable in the literature (e.g. George, \& Mallery, 2003), this survey seems to be of acceptable reliability.

Following the analysis concerning validation, the frequency analysis was carried out to reveal what the respondents thought about each item in the questionnaire. Then, in order to determine if there are meaningful differences between male and female respondents and between ELT graduates and non-ELT graduates, statistical analysis included independent samples t-test. The item that asked about the degree held by the respondent was also analysed through this test since there were no teachers with a Ph.D. degree although it was written as an option for this item, so two options were left for the item in question. The results of this analysis are the point that I turn to in the following section.

\section{Results and Discussions}

The results of the questionnaire were analysed to obtain detailed information about the ideas of the English language teacher on constructivist language pedagogy. Frequency distribution and the percentage of each item in the survey is given in the tables below. Though there might be genuine reasons for the given distribution of a specific item, some reasons make themselves clear. These potential reasons are discussed in the paragraphs below the tables.

Table 3. Frequencies of the items on actual classroom practices

\begin{tabular}{|c|c|c|c|c|c|c|c|c|c|c|c|c|}
\hline \multirow{2}{*}{$\begin{array}{l}\text { Items } \\
1-10\end{array}$} & \multicolumn{2}{|c|}{ Always } & \multicolumn{2}{|c|}{ Frequently } & \multicolumn{2}{|c|}{ Sometimes } & \multicolumn{2}{|c|}{ Rarely } & \multicolumn{2}{|c|}{ Never } & \multicolumn{2}{|c|}{ Missing } \\
\hline & Freq & $\%$ & Freq & $\%$ & Freq & $\%$ & Freq & $\%$ & Freq & $\%$ & Freq & $\%$ \\
\hline Item-1 & 14 & 17.3 & 30 & 37.0 & 25 & 30.9 & 6 & 7.4 & 5 & 6.2 & 1 & 1.2 \\
\hline Item-2 & 27 & 33.3 & 38 & 46.9 & 12 & 14.8 & 2 & 2,5 & 1 & 1.2 & 1 & 1.2 \\
\hline Item-3 & 13 & 16.0 & 39 & 48.1 & 26 & 32.1 & 2 & 2.5 & 0 & 0 & 1 & 1.2 \\
\hline Item-4 & 65 & 80.2 & 10 & 12.3 & 4 & 4.9 & 0 & 0 & 0 & 0 & 2 & 2.5 \\
\hline Item-5 & 16 & 19.8 & 23 & 28.4 & 32 & 39.5 & 8 & 9.9 & 1 & 1.2 & 1 & 1.2 \\
\hline Item-6 & 27 & 33.3 & 41 & 50.6 & 9 & 11.1 & 1 & 1.2 & 2 & 2.5 & 1 & 1.2 \\
\hline Item-7 & 24 & 29.6 & 40 & 49.4 & 14 & 17.3 & 2 & 2.5 & 0 & 0 & 1 & 1.2 \\
\hline Item-8 & 6 & 7.4 & 29 & 35.8 & 30 & 37.0 & 12 & 14.8 & 2 & 2.5 & 2 & 2.5 \\
\hline Item-9 & 9 & 11.1 & 29 & 35.8 & 31 & 38.3 & 11 & 13.6 & 1 & 1.2 & 0 & 0 \\
\hline Item-10 & 23 & 28.4 & 35 & 43.2 & 18 & 22.2 & 4 & 4.9 & 0 & 0 & 1 & 1.2 \\
\hline
\end{tabular}

Being a significant aspect of a constructivist classroom, learners' taking part in the planning process seems to be readily accepted and practised by teachers; only 6.2 per cent of the respondents never give learners the chance to be involved in planning. With reference to making learners autonomous researchers (Item-2), the respondents are apparently willing to support and encourage learner involvement on individual research. It follows from this that teachers agree with the idea that learners have to reach reliable sources of data on their own. By getting reliable information, learners may become involved in knowledge construction by synthesizing the old and the new. 
constructivist objectives for learning with appropriate types of instruction and assessment or to adapt constructivist principles to their particular classroom contexts (Windschitl, 2002, 138).

Practise is even more difficult for teachers whose students desire to seek clear explanations for abstract grammar points. That is, how learners view their teachers is also important because, for example, one teacher said, "The teachers who purely practice instructivist pedagogy are viewed as knowledgeable, while those having a constructivist orientation are seen as inefficient". This is because constructivist classrooms neither emphasise knowledge transmission nor they are after discovery learning.

\section{Conclusions}

For a long period of time formalist approaches to language teaching have deluged the language teaching profession in Turkey until recently when there was an attempt at introducing constructivism into the foreign language curricula of primary schools in 2005. The roots of the curricular shift can be traced back to the frequently expressed but never practised belief that learners should learn to learn and be involved in the learning process. This belief works in harmony with one of the basic premises of the constructivist schools of thought; that is, learning by knowledge construction rather than knowledge absorption. The way teachers view how learners gain knowledge; that is, what they think as to whether learners passively receive information or build up knowledge, deeply affect and shape the nature of how a lesson proceeds. Such a difference in theoretical and practical view determines whether a teacher is following an instructivist or constructivist approach. However, it is not an easy job to conform to the latter. Brooks and Brooks (1999) tell us why is rather difficult to become a constructivist teacher:

"For many educators, becoming a constructivist teacher requires a paradigm shift. Becoming such a teacher means much more than appending new practices to already full repertoires. For many, it requires the willing abandonment of familiar perspectives and practices and the adoption of new ones" (Brooks, \& Brooks 1999, 25).

Similarly, White $(2001,70)$ makes the point that to make changes in perspectives, getting accustomed to these changes is significant. Changes begin in theoretical aspects; then they are seen in practical points. In order for the curricular changes to take place, teachers should try to get a full understanding of the theoretical issues regarding constructivism though being acquainted with the theory is rarely sufficient for successful implementation. Teachers should also be willing to implement the constructivist principles in the classroom. This actually covers the motivational aspect of teaching on the part of the teachers.

As the overall study has told us, the transition from instructivist teaching to constructivist pedagogies necessitates effort and time because such transition entails clear models to follow, theoretical knowledge and practical experience, in addition to motivation on the part of both teachers and learners. Finding others who have experience helps in this transition, because few or no instructors have themselves been taught in a constructivist classroom before, and it is sometimes difficult to depict how a constructivist class operates or to guess all the challenges one might experience. Primary school English teachers in Turkey seem to have come to an understanding of constructivism in an overall sense though they have serious difficulties in terms of practice. One tentative conclusion from this survey can be that teachers perhaps need more in-service training on how to put constructivist principles into practice in the classroom. This might help them to eliminate persistent problems. 


\section{Section III:}

In this section, we mostly deal with in-class challenges regarding constructivist pedagogy. For each item choose the option that suits your situation best.

\begin{tabular}{|c|c|c|c|c|c|}
\hline $\begin{array}{ll}\text { Strongly Agree } & : 5 \\
\text { Agree } & : 4 \\
\text { No Idea } & : 3 \\
\text { Disagree } & : 2 \\
\text { Strongly Disagree } & : 1\end{array}$ & 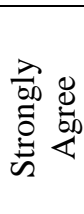 & 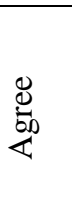 & 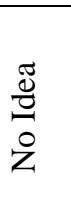 & 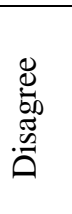 & 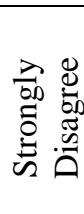 \\
\hline 11. I enjoy teaching in a constructivist language class. & 5 & $\begin{array}{c}4 \\
()\end{array}$ & $\begin{array}{l}3 \\
()\end{array}$ & $\begin{array}{c}2 \\
()\end{array}$ & $\begin{array}{l}1 \\
()\end{array}$ \\
\hline $\begin{array}{l}\text { 12. It takes more time for the students to learn in a } \\
\text { constructivist class. }\end{array}$ & 5 & $\begin{array}{c}4 \\
()\end{array}$ & 3 & 2 & $\begin{array}{l}1 \\
()\end{array}$ \\
\hline $\begin{array}{l}\text { 13. Available class time is not enough to follow a constructivist } \\
\text { approach. }\end{array}$ & 5 & $\begin{array}{c}4 \\
()\end{array}$ & 3 & 2 & 1 \\
\hline $\begin{array}{l}\text { 14. The responsibility of the teacher becomes heavier in a } \\
\text { constructivist class. }\end{array}$ & $\begin{array}{l}5 \\
()\end{array}$ & $\begin{array}{c}4 \\
()\end{array}$ & $\begin{array}{c}3 \\
()\end{array}$ & $\begin{array}{c}2 \\
()\end{array}$ & $\begin{array}{c}1 \\
()\end{array}$ \\
\hline $\begin{array}{l}\text { 15. In a constructivist class, learning appears "less efficient" } \\
\text { than in a traditional one. }\end{array}$ & 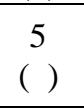 & $\begin{array}{c}4 \\
()\end{array}$ & $\begin{array}{l}3 \\
()\end{array}$ & $\begin{array}{c}2 \\
()\end{array}$ & $\begin{array}{l}1 \\
()\end{array}$ \\
\hline $\begin{array}{l}\text { 16. I have difficulties in putting constructivist principles into } \\
\text { practice in my classes. }\end{array}$ & $\begin{array}{l}5 \\
(~)\end{array}$ & $\begin{array}{l}4 \\
()\end{array}$ & $\begin{array}{l}3 \\
()\end{array}$ & $\begin{array}{c}2 \\
()\end{array}$ & 1 \\
\hline $\begin{array}{l}\text { 17. There is a gap between constructivist theory and current } \\
\text { practice in the classrooms. }\end{array}$ & $\begin{array}{c}5 \\
(\text { ) }\end{array}$ & $\begin{array}{c}4 \\
()\end{array}$ & $\begin{array}{c}3 \\
()\end{array}$ & $\begin{array}{c}2 \\
()\end{array}$ & $\begin{array}{c}1 \\
()\end{array}$ \\
\hline
\end{tabular}

\section{Section IV: The Course Book}

Choose one of the course books below to evaluate it in the in the section below.

$\square$ Time for English (Grade 4)

$\square$ Time for English (Grade 5)

$\square$ Spot on (Grade 6)

$\square$ Spot on (Grade 7)

$\square$ Spot on (Grade 8)

$\square$ Other (Please specify: .)

In this section you are asked to evaluate the course book you have chosen in the previous section from a constructivist viewpoint.

\begin{tabular}{|c|c|c|c|c|c|}
\hline $\begin{array}{ll}\text { Strongly Agree } & : 5 \\
\text { Agree } & : 4 \\
\text { Undecided } & : 3 \\
\text { Disagree } & : 2 \\
\text { Strongly Disagree } & : 1\end{array}$ & 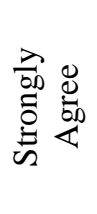 & 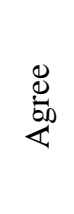 & $\begin{array}{l}\frac{\pi}{\mathbb{Z}} \\
\frac{0}{2} \\
z\end{array}$ & 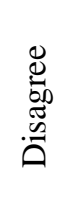 & 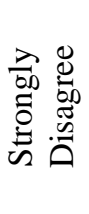 \\
\hline $\begin{array}{l}\text { 18. I think the constructivist activities in the book are enjoyable } \\
\text { for my students. }\end{array}$ & $\begin{array}{l}5 \\
()\end{array}$ & $\begin{array}{c}4 \\
()\end{array}$ & $\begin{array}{l}3 \\
(~)\end{array}$ & $\begin{array}{l}2 \\
(~)\end{array}$ & $\begin{array}{l}1 \\
()\end{array}$ \\
\hline $\begin{array}{l}\text { 19. The activities in the book allow the learners to take } \\
\text { decisions. }\end{array}$ & $\begin{array}{c}5 \\
(()\end{array}$ & $\begin{array}{c}4 \\
( \\
(\end{array}$ & $\begin{array}{l}3 \\
()\end{array}$ & $\begin{array}{c}2 \\
()^{2}\end{array}$ & $\begin{array}{c}1 \\
(()\end{array}$ \\
\hline 20. The activities in the course book are problem-centred. & $\begin{array}{l}5 \\
()\end{array}$ & $\begin{array}{c}4 \\
()\end{array}$ & $\begin{array}{c}3 \\
()\end{array}$ & 2 & $\begin{array}{c}1 \\
()\end{array}$ \\
\hline $\begin{array}{l}\text { 21. The course book includes activities or questions that make } \\
\text { learners think. }\end{array}$ & 5 & $\begin{array}{c}4 \\
(~)\end{array}$ & 3 & $\begin{array}{l}2 \\
(~)\end{array}$ & $\begin{array}{c}1 \\
(\mathrm{l})\end{array}$ \\
\hline
\end{tabular}




\begin{tabular}{|c|c|c|c|c|c|}
\hline $\begin{array}{l}\text { 22. The course book encourages learners to do research on their } \\
\text { own. }\end{array}$ & $\begin{array}{c}5 \\
(~)\end{array}$ & $\begin{array}{l}4 \\
(~)\end{array}$ & $\begin{array}{l}3 \\
(~)\end{array}$ & $\begin{array}{l}2 \\
(~)\end{array}$ & $\begin{array}{l}1 \\
(\mathbf{~ ) ~}\end{array}$ \\
\hline 23. I think the workbook follows a constructivist approach. & $\begin{array}{l}5 \\
()^{2}\end{array}$ & $\begin{array}{c}4 \\
()\end{array}$ & $\begin{array}{c}3 \\
()\end{array}$ & $\begin{array}{c}2 \\
(~)\end{array}$ & $\begin{array}{l}1 \\
(\boldsymbol{~})\end{array}$ \\
\hline $\begin{array}{l}\text { 24. The te } \\
\text { constr }\end{array}$ & 5 & $\begin{array}{c}4 \\
()\end{array}$ & $\begin{array}{l}3 \\
(1)\end{array}$ & 2 & 1 \\
\hline $\begin{array}{l}\text { 25. The course book is compatible with the syllabus provided } \\
\text { by the Ministry of Education. }\end{array}$ & $\left(\begin{array}{l}5 \\
() \\
\end{array}\right.$ & $\begin{array}{l}4 \\
(~) \\
\end{array}$ & $\begin{array}{l}3 \\
(~)\end{array}$ & $\stackrel{2}{()}$ & 1 \\
\hline $\begin{array}{l}\text { 26. The course book complies with constructivist principles in } \\
\text { general. }\end{array}$ & $\begin{array}{c}5 \\
(~)\end{array}$ & $\begin{array}{c}4 \\
\text { ( ) }\end{array}$ & $\begin{array}{c}3 \\
\text { ( ) }\end{array}$ & $\begin{array}{l}2 \\
(\text { ) }\end{array}$ & $\begin{array}{l}1 \\
\text { ( ) }\end{array}$ \\
\hline
\end{tabular}

\section{THANKS FOR YOUR PARTICIPATION}

Note: Contact name and e-mail address are given below in case you need. Please feel free to get in touch to get a summary of the findings if you are interested.

E-mail Address: arifbakla@yahoo.com

Your E-mail Address:

\section{Appendix B}

Detailed Statistics about the Course Books for Each Grade

Table 6. Statistics per book (Items 18-26)

\begin{tabular}{|c|c|c|c|c|c|c|}
\hline & \multicolumn{6}{|c|}{ Time for English (Grade 4) } \\
\hline & $\begin{array}{l}\text { Strongly } \\
\text { Agree }\end{array}$ & Agree & No Idea & Disagree & $\begin{array}{l}\text { Strongly } \\
\text { Disagree }\end{array}$ & Missing \\
\hline Item-18 & 3 & 3 & 2 & 1 & 0 & 0 \\
\hline Item-19 & 0 & 6 & 1 & 2 & 0 & 0 \\
\hline Item-20 & 1 & 2 & 3 & 3 & 0 & 0 \\
\hline Item-21 & 3 & 5 & 0 & 1 & 0 & 0 \\
\hline Item-22 & 0 & 4 & 3 & 2 & 0 & 0 \\
\hline Item-24 & 0 & 4 & 2 & 2 & 1 & 0 \\
\hline Item-25 & 1 & 6 & 1 & 1 & 0 & 0 \\
\hline \multirow[t]{3}{*}{ Item-26 } & 0 & 4 & 3 & 2 & 0 & 0 \\
\hline & \multicolumn{6}{|c|}{ Time for English (Grade 5) } \\
\hline & $\begin{array}{c}\text { Strongly } \\
\text { Agree }\end{array}$ & Agree & No Idea & Disagree & $\begin{array}{l}\text { Strongly } \\
\text { Disagree }\end{array}$ & Missing \\
\hline Item-18 & 0 & 4 & 0 & 8 & 2 & 0 \\
\hline Item-19 & 0 & 4 & 1 & 9 & 0 & 0 \\
\hline Item-20 & 0 & 7 & 2 & 4 & 1 & 0 \\
\hline Item-21 & 0 & 6 & 1 & 6 & 1 & 0 \\
\hline Item-22 & 0 & 2 & 2 & 8 & 1 & 0 \\
\hline Item-24 & 0 & 5 & 5 & 1 & 3 & 0 \\
\hline Item-25 & 0 & 5 & 3 & 4 & 2 & 0 \\
\hline \multirow[t]{3}{*}{ Item-26 } & 1 & 3 & 3 & 6 & 1 & 0 \\
\hline & \multicolumn{6}{|c|}{ Spot on (Grade 6) } \\
\hline & $\begin{array}{c}\text { Strongly } \\
\text { Agree }\end{array}$ & Agree & No Idea & Disagree & $\begin{array}{l}\text { Strongly } \\
\text { Disagree }\end{array}$ & Missing \\
\hline Item-18 & 1 & 6 & 1 & 1 & 1 & 0 \\
\hline Item-19 & 0 & 5 & 3 & 2 & 0 & 0 \\
\hline Item-20 & 0 & 6 & 2 & 0 & 1 & 0 \\
\hline
\end{tabular}




\begin{tabular}{|c|c|c|c|c|c|c|}
\hline Item-21 & 3 & 6 & 0 & 1 & 0 & 0 \\
\hline Item-22 & 2 & 3 & 1 & 4 & 0 & 0 \\
\hline Item-24 & 2 & 5 & 0 & 2 & 1 & 0 \\
\hline Item-25 & 1 & 4 & 0 & 3 & 1 & 0 \\
\hline \multirow[t]{3}{*}{ Item-26 } & 0 & 6 & 1 & 2 & 1 & 0 \\
\hline & \multicolumn{6}{|c|}{ Spot on (Grade 7) } \\
\hline & $\begin{array}{l}\text { Strongly } \\
\text { Agree }\end{array}$ & Agree & No Idea & Disagree & $\begin{array}{l}\text { Strongly } \\
\text { Disagree }\end{array}$ & Missing \\
\hline Item-18 & 3 & 5 & 0 & 2 & 1 & 0 \\
\hline Item-19 & 2 & 3 & 2 & 3 & 1 & 0 \\
\hline Item-20 & 1 & 6 & 3 & 0 & 1 & 0 \\
\hline Item-21 & 1 & 5 & 1 & 3 & 1 & 0 \\
\hline Item-22 & 1 & 3 & 3 & 3 & 1 & 0 \\
\hline Item-24 & 4 & 4 & 0 & 1 & 2 & 0 \\
\hline Item-25 & 1 & 5 & 4 & 0 & 1 & 0 \\
\hline \multirow[t]{3}{*}{ Item-26 } & 0 & 6 & 2 & 2 & 1 & 0 \\
\hline & \multicolumn{6}{|c|}{ Spot on (Grade 8) } \\
\hline & $\begin{array}{l}\text { Strongly } \\
\text { Agree }\end{array}$ & Agree & No Idea & Disagree & $\begin{array}{l}\text { Strongly } \\
\text { Disagree }\end{array}$ & Missing \\
\hline Item-18 & 1 & 6 & 1 & 9 & 1 & 0 \\
\hline Item-19 & 1 & 8 & 3 & 6 & 0 & 0 \\
\hline Item-20 & 0 & 11 & 3 & 3 & 0 & 0 \\
\hline Item-21 & 5 & 7 & 4 & 2 & 0 & 0 \\
\hline Item-22 & 1 & 5 & 3 & 8 & 1 & 0 \\
\hline Item-24 & 3 & 7 & 6 & 2 & 0 & 0 \\
\hline Item-25 & 3 & 7 & 2 & 4 & 2 & 0 \\
\hline Item-26 & 0 & 9 & 4 & 4 & 1 & 0 \\
\hline
\end{tabular}

